\title{
下水処理水の工程別臭気の解析と臭気低減対策
}

\author{
青木畺 -**杉 本博之*馬場 大 哉**
}

\section{Analysis of Odor Compounds in Sewerage Process Water and Deodor Methods}

\author{
Shimich AOKI* , Hiroyuki SUGIMOTO* and Daiya BAMBA** \\ * Touhokubu Office of Shiga Prefuctual Sewerage Management Public Corporation, Ohhora 1550, Matsubara-cho, \\ Hikone, Shiga 522-0002, Japan \\ * Environment Science Technology Division, Toray Techno Co., Ltd., Sonoyama 1-1-1, Otsu, Shiga 520-8558, \\ Japan
}

\begin{abstract}
The concentration of 21 odor compounds of water and air, odor index and DOC of the water were measured at nine sewerage process stations. The odor indexes of water decreased as the sewage treatment progressed. According to the dilution ratio given by dividing the concentration of an odor compound in the head space of a triangle flask with its threshold, it was suggested that sulfur-containing compounds are the main cause of odor at the upstream treatment process including the biological reaction process. Since the odor index obtained by the triangle flask method had a positive correlation with the concentration of aldehydes in water, it was suggested that the decrease in odor index depends on the concentration of aldehydes. The dilution ratios in air supported the suggestion that sulfur-containing compounds are the main cause of odor at the upstream treatment process, and acetaldehyde is the main cause of odor at the outflow of final sedimentation and final effluent. The concentration of acetaldehydes of air at the final effluent was 15 times as high as that of a natural environment. Deodor methods by both photocatalysis and ozonation treatment were considered feasible for decreasing the odor of the final effluent.
\end{abstract}

Key words : odor index, odor compounds, triangle flask method, ozone, photocatalyst

\section{1.はじめに}

悪真防止法（以下，「法」という）に上る事業場から の悪臭に対する規制が，2000年 6 月に一部改正され， 排出水の臭気指数が規制基準に追加された。この基準で は，都道拊県知事によって指定される区域每に，排出水 の悪臭物質の濃度または 3 点比較式フラスコ法による臭 気指数のいずれかで規制することが定められている。滋 賀県琵琶湖流域下水道東北部処理区東北部浄化センター (以下，「本処理場」という)がある滋賀県彦根市では， 法に基づき，2003 年 9 月から放流水の具気指数に上る 規制が適用されている。

本処理場の放流水は，彦根旧港湾に放流されている。 放流後の水の一部は，彦根市が彦根城の堀を浄化するた めに導水されている。現在, 本処理場の放流水は臭気指 数の規制基準值の 28 以下であるが，乙の臭気管理打よ び臭気の低減対策は，放流先の水環境䘮保全する上で重 要である。

放流水中の臭気物質过処理原水に存在寸るか処理工程 で発生した物質であるため，放流水中の臭気物質を管理
する上で，下水処理場の処理工程每の水中の臭気物質の 濃度变化を知ることや，その物質が水の臭気指数に与え る影響を知ることが必要になる。

しかしながら，下水処理工程别の奥気物質について， 大気中の物質濃度は測定例があるが，稼働している処理 施設での水中の物質濃度の測定例は見られないいら。そ こで本研究では，本処理場の放流水を含む下水処理工程 9 ヶ所で，21種の臭気物質の大気中の物質浱度，水中の 物質濃度および水の臭気指数老測定し，それらの関係を 解析した。また, 一般環境と比較するため, 自然的な水 環境での大気中の臭気物質の濃度と水の臭気指数を測定 Lた。

さらに，放流水の臭気低減対策として，将来下水の超 高度処理として導入の可能性があるオゾンと生物活性炭 を組み合わせた方法，および光触媒布と紫外線を使用し た方法について検討した。

\section{2. 方法}

本処理場内の調查は，処理工程の最上流であるポンプ

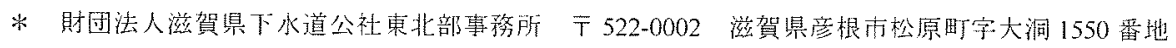

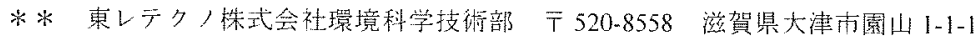




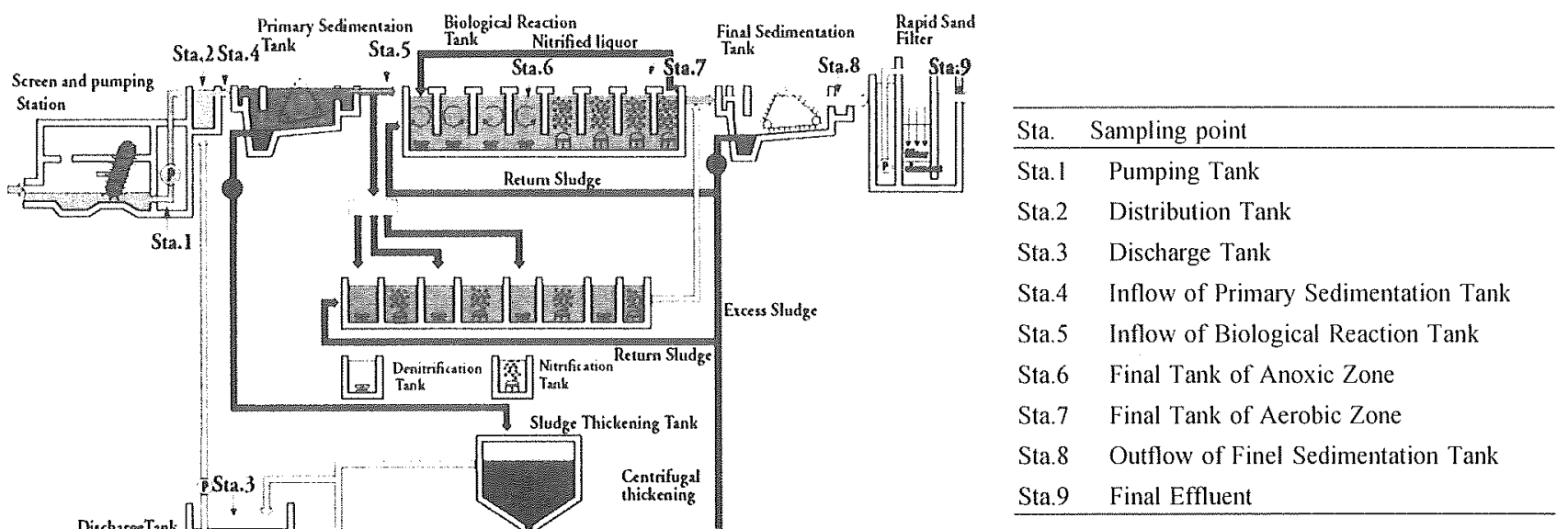

Table 1 Measured Odor Compounds and Analysis Methods

\begin{tabular}{|c|c|c|c|c|c|c|}
\hline & \multirow[b]{2}{*}{ Odor Compounds } & \multicolumn{2}{|c|}{ Detection Limit } & \multirow{2}{*}{$\frac{\text { Threshold }}{\text { Air }}$} & \multirow{2}{*}{$\begin{array}{l}\text { Henry's Law } \\
\text { Constant }\end{array}$} & \multirow[b]{2}{*}{ Analysis Method" } \\
\hline & & Air & Water & & & \\
\hline 1 & Hydrogen Sulfide & 0.2 & 1 & 0.5 & $867 \quad\left(20^{\circ} \mathrm{C}\right)$ & Air ; Bag collecting/GC-FPD \\
\hline 2 & Methyl Mercaptan & 0.2 & 1 & 0.12 & $\left(25^{\circ} \mathrm{C}\right)$ & Water Headspace at $30^{\circ} \mathrm{C} / \mathrm{GC}-\mathrm{FPD}$ \\
\hline 3 & Dimethyl Sulfide & 0.2 & 1 & 0.12 & $\left(25^{\circ} \mathrm{C}\right)$ & \\
\hline 4 & Dimethyl Disulfide & 0.2 & 1 & 0.28 & $123 \quad\left(20^{\circ} \mathrm{C}\right)$ & \\
\hline 5 & Anmonia & 50 & 40 & 150 & $1.63\left(25^{\circ} \mathrm{C}\right)$ & Air ; Spectrometer Water ; Headspase/GC \\
\hline 6 & Acetaldehyde & 0.2 & 0.3 & 1.5 & $6.76\left(25^{\circ} \mathrm{C}\right)$ & Air $; 6-11$ Bag collecting/GC-MS \\
\hline 7 & Propionaldehyde & 0.2 & 0.3 & 1.5 & $7.44\left(25^{\circ} \mathrm{C}\right)$ & 12 DNPHube/ANextract/HPI C \\
\hline 8 & n-Butylaldehyde & 0.2 & 0.3 & 0.32 & - & 12 DNPHtube/ANextract./HPLC \\
\hline 9 & Isobutylraldehyde & 0.2 & 0.3 & 0.9 & - & Water ; PFBOAderivation/hexan extract/GC-MS \\
\hline 10 & n-Valeraldehyde & 0.2 & 0.3 & 0.71 & $\left(25^{\circ} \mathrm{C}\right)$ & \\
\hline 11 & Isovaleraldehyde & 0.2 & 0.3 & 0.19 & - & \\
\hline 12 & Formaldehyde & 10 & 1 & 410 & $0.03\left(25^{\circ} \mathrm{C}\right)$ & \\
\hline 13 & Propionic Acid & 0.05 & 1 & 2.4 & - & Air ; Strontium tube/GC-MS \\
\hline 14 & n-Butyric Acid & 0.05 & 1 & 0.068 & - & Water ; Extract with diethylether:hexane $(3: 2) /$ \\
\hline 15 & n-Valeric Acid & 0.05 & 1 & 0.4 & - & Water, Exirac win dienyletner.nexane(3.2)! \\
\hline 16 & Isovaleric Acid & 0.05 & 1 & 0.053 & - & GC-MS \\
\hline 17 & 2-Methylisoborneol & 0.05 & 0.01 & - & $0.90\left(25^{\circ} \mathrm{C}\right)$ & Air ; 20 Bag collecting/GC-MS \\
\hline 18 & Geosmin & 0.05 & 0.01 & 6.5 & $1.20\left(25^{\circ} \mathrm{C}\right)$ & else Mulibet tube/GC-MS \\
\hline 19 & Isoborneol & 0.05 & 0.01 & - & - & eIse MAUIbet tude/UC-MS \\
\hline 20 & Camphene & 0.05 & 0.01 & - & - & Water : Extract with hexane/GC-MS \\
\hline 21 & Camphor & 0.05 & 0.01 & - & $8.21\left(25^{\circ} \mathrm{C}\right)$ & \\
\hline
\end{tabular}

井から最下流の放流水の閒の9地点で行った。処理工程 の模式図および採取地点をFig.1に示した。本処理場の 規模は 2003 年 4 月 1 日現在で管渠延長約 $95 \mathrm{~km}$, 処理能 力は $63,000 \mathrm{~m}^{3} \cdot \mathrm{d}^{-1}$ であり，処理方式は，凝集剤添加活性 污泥循環変法十砂乃過法, 㧍上び凝集剂添加多段硝化脱 空法十砂万過法を有しており，本調查は前者で行った。 2002 年 8 月 23 日に各地点で, 工程水の採水および工程 水直上 $10 \mathrm{~cm}$ の大気中の莫気物質を採取した。测定項目 および分析方法を Table 1 に示した。测定項目は事前の 定性分析で検出された物質と悪臬 22 物質から選定した。 水試料はガラス製容器に採取した徭泠蔵し, 臭気指数は 24 時間以内に, 他の項目は 72 時間以内に分析に供した。 含硫黄化合物は GC-FPD を用い, アンモニアの大気試料 は比色法で，水試料はへッドスペース-GC 法で，アルデ ヒド類はバッグ捕集後 GC-MS または DNPH 捕集後 HPL C 法で，水試料はPFBOA で抽出後へキサン整縮し GCMS 法で，有機酸類の大気試料はチューブ捕集後 GC-MS 法で, 水試料はジメチルエーテル抽出後へキサン濃縮し
GC-MS 法で，テルペン類の大気試料は，バッグまたは チューブ捕集後 GC-MS 法で, 水試料はへキサン抽出後 GC-MS 法で分析を行った。水の臭気指数は三点比較式 フラスコ法で, 溶存有機炭素(DOC)は, 乃過後島津 TOC 計で測定した。三点比較式フラスコ法による水の臭気指 数は，試料水をへッドスペースのあるフラスコ内で 25 ${ }^{\circ} \mathrm{C}$ に保ち，へッドスペース中の物質濃度と水中の物質濃 度が平衡に達した時点での，へッドスペース中の臭気を 官能法により調べる方法である゙。官能法による臭気の 測定は，人の嗅覚による臭気の測定方法であり，試料水 を段階的に希啋しながら測定を繰り返し，莫わなくなっ た時点の希橎倍率を元に臭気指数を算出寸る方法であ 万。

自然的な水環境での調查は，滋賀県米原町にある蓮池 （Fig. 2(A)）亡滋賀県びわ町にある早㥓内湖（Fig.2(B)） で行った。2003 年10月 28 日に, 両地点で採水执よび 直上 $10 \mathrm{~cm}$ の大気中の臭気物翼を採取した。オン゙ン処理 と生物活性炭処理老組夕合孔せた方法による臭気低隇実 
験は，まず，本処理場の放流水を原水としオジン処理を 行い, オゾン処理後の水を生物活性炭処理する方法とし た。実験装置の模式图をFig. 3(A)に示した。実験は 2003 年11月14日に開始し，14日間運転した後に試料を採 取し，水の臭気指数および本処理場の調查で測定対象と した21物質の水中の灙度を測定した。

光触媒布学用いた方法は，本処理場の放流水を原水之 し，これを，あらかじめ光触媒布を敷いた水路に滞留時 間が 10 分になるように流入させた。実験装置の模式図 をFig. 3(B)に示した。実験は2003年12月15日に開始 し，4週間後に試料を採取し，水中の臭気指数を测定し た。なお 3 水準の紫外線強度 $\left(0.45,0.92,2.26 \mathrm{~mW} \cdot \mathrm{cm}^{-2}\right)$ について検討を行った。オゾン処理, 生物活性炭処理条 件および光触媒布上紫外線処理条件を Table 2, 3 および 纪示した。

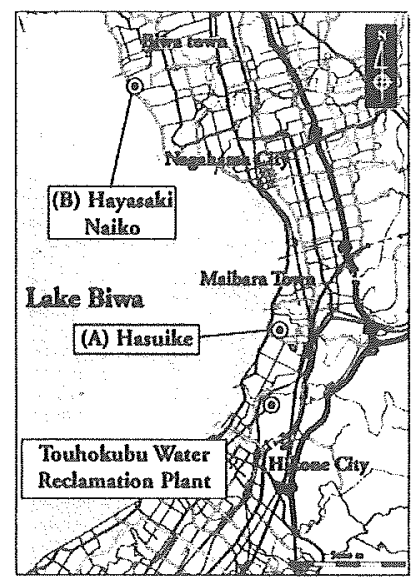

Fig. 2 Sampling Points of Natural Environment

(A)

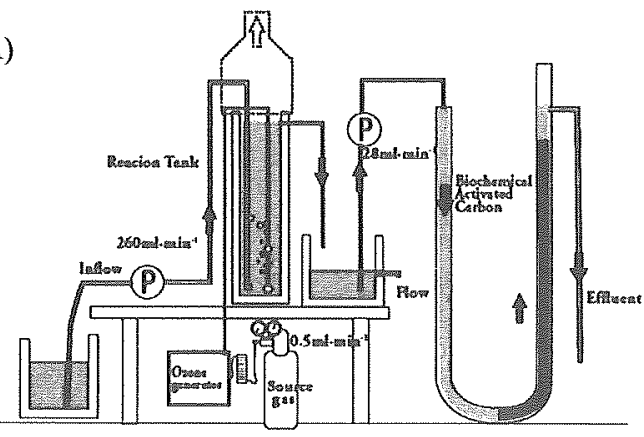

(B)

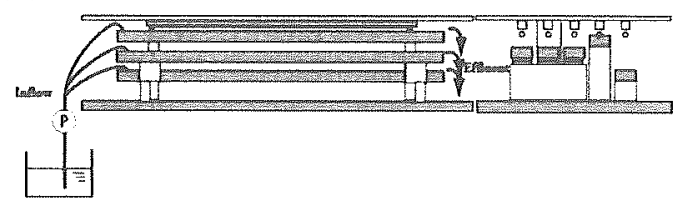

Fig. 3 Deodor Experiment Equipment

(A): Ozone and Biochemical activated carbon Treatment

(B): Photo-catalyst and Ultra-violet Treatment
Table 2 Ozone Treatment Conditions

\begin{tabular}{ll}
\hline Item & Value \\
\hline Hydraulic Retention Time & 15 minutes (=Dirution Time) \\
Inflow & $260 \mathrm{~m} / \cdot \mathrm{min}^{-1}$ \\
Reaction Tank & $100 \varphi \times 500 \mathrm{~mm}(3.9 l)$ \\
Ozone Pouring Rate & $10 \mathrm{mg} \cdot l^{-1} \cdot \mathrm{min}^{-1}$ \\
Current Direction & Upword \\
Ozone generator & ED-OG-A2(Ecodezine ltd.) \\
Source gas & High Quality Oxzen \\
\hline
\end{tabular}

Table 3 Biochemical Activated Carbon Treatment Conditions

\begin{tabular}{ll}
\hline Item & Value \\
\hline Linear Velocity & $2.23 \mathrm{~cm} \cdot \mathrm{cm}^{-2}$ \\
Hydraulic Retention Time & $17.2 \mathrm{~min}$ \\
Reaction Cylinder & $40 \varphi \times 2000 \mathrm{~mm}(2.57)$ \\
Crevice Rate & $18 \%($ Crevice Volume $450 \mathrm{~m} /)$ \\
Inflow & $26 \mathrm{~m} / \cdot \mathrm{min}^{-1}$ \\
Activate Carbon & $\varphi 0.5 \mathrm{~mm}$ \\
& (Kureha Cemical Co.,Ltd.) \\
Current Direction & Upword \\
\hline
\end{tabular}

Table 4 Photo-catalyst and Ultra-violet Treatment Conditions

\begin{tabular}{ll}
\hline \multicolumn{1}{c}{ Item } & Value \\
\hline Photo-catalyst & $6 \mathrm{~g}-\mathrm{TiO}_{2} \cdot \mathrm{m}^{-2}$ \\
Photo-catalyst Cloth & Examination Cloth \\
& (TORAY Industries Co.,Ltd.) \\
Ultra-violet Intensity & $0.45,0.92,2.26 \mathrm{~mW} \cdot \mathrm{cm}^{-2}$ \\
Wave length & $252 \mathrm{~nm}$ \\
Hydraulic Retention Time & $10 \mathrm{~min}$ \\
\hline
\end{tabular}

3. 結果

\section{1 臭気物質濃度および臭気指数の測定結果}

各採取地点の臭気物質濃度臭気指数および DOC の測 定結果をTable 5およびTable 6に示した。これによる と，メチルメルカプタン，二硫化メチルおよびテルペン 類を除き，水中で検出された物質は，上流工程ほど高い 濃度であるが，下流工程ほど濃度が低くなる傾向が見ら れた。大気中の濃度では，硫化水素，メチルメルカプタ ン，硫化メチル执よび二硫化メチルといった含硫黄化合 物では，上流工程で濃度が高く，下流工程で濃度が低く なる傾向が見られた。アセトアルデヒドは，同様の傾向 があるものの，下流工程でも含硫黄化合物と比心゙ると濃 度が高い傾向が見られた。水の臭気指数および DOCに ついても下流工程ほど低くなる傾向が見られ，水処理が 進むりど悪臭も低減されていた。

自然的な水環境での測定結果を Fig. 4に示した。比較 のため本処理場の放流水での測定值（2002 年）を示し た。これによると，蓮池での水の臭気指数が検出限界以 下(<3)であったが，早崎内湖では11であり本処理場の 放流水で測定された值と同じであった。また，放流水直 上の大気中のアセトアルデヒド濃度は，自然的な水環境 の大気中の濃度の15 倍程度であった。自然的な水環境 ではアセトアルデヒド以外のアルデヒド類が険出された が，その濃度は低いもので女った。

\section{2 臭気低減対策実験結䱊}

オゾン処理と生物活性炭処理に上る水の臬気低減実験 の結果，原水の濃度が定量下限值を上回った物質の濃度 変化をFig. 5 に示した。二れによると臭気指数は，原水 では11であったのが，才ゾン処理後には８となり，生 物活性炭処理後には測定限界以下(<3)であった。また， 
オゾン処理後および生物活性炭処理後では，水中のアン モニア，プロピオン酸，ノルマルブチルアルデヒドおよ びイソ吉草酸の濃度が低下していた。光触媒布之紫外線 による処理結果をFig. 6 に示した。これによると，原水
の臭気指数が 16 であったのが紫外線強度 $0.45 \mathrm{~mW} \cdot \mathrm{cm}^{-2}$ での処理後では 8 , 紫外線強度 0.92 求よび $2.26 \mathrm{~mW} \cdot \mathrm{cm}^{-2}$ では6であった。

Table 5 Concentration of Odor Compounds in The Water of The Sawerage Processes

$\mu \mathrm{g} \cdot l^{-1}$

\begin{tabular}{|c|c|c|c|c|c|c|c|c|c|c|c|c|c|c|c|c|c|c|c|c|c|c|c|}
\hline 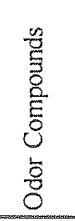 & 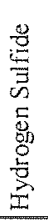 & 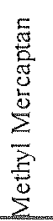 & 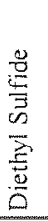 & 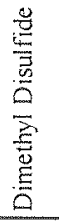 & 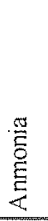 & 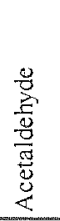 & 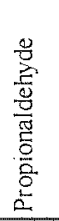 & 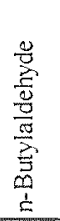 & $\begin{array}{l}\frac{0}{2} \\
\frac{2}{2} \\
\frac{0}{8} \\
\frac{\pi}{2} \\
\frac{2}{2} \\
\frac{1}{0} \\
\frac{1}{0} \\
0\end{array}$ & 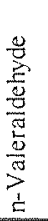 & 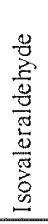 & 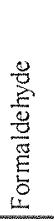 & 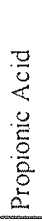 & 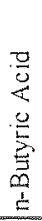 & 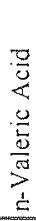 & 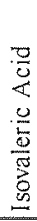 & 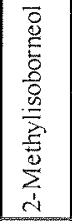 & $\begin{array}{l}5 \\
\bar{E} \\
0 \\
0\end{array}$ & $\begin{array}{l}\overline{0} \\
\stackrel{8}{0} \\
\overline{8} \\
8 \\
0\end{array}$ & 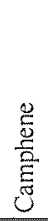 & 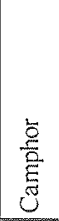 & 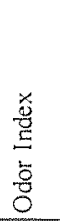 & $\begin{array}{l}\underset{\Xi}{0} \\
\stackrel{0}{E} \\
\dot{O} \\
\stackrel{0}{0}\end{array}$ \\
\hline Sta. I & 13 & 100 & 3 & 4 & 32 & 220 & 66 & 74 & 7 & - & - & 130 & - & - & & - & 0.04 & 0.02 & 0.13 & - & 0.19 & 33 & 40 \\
\hline Sta.2 & 38 & 62 & 6 & - & 24 & 830 & 320 & 230 & 24 & 10 & - & 470 & - & - & - & - & 0.03 & 0.01 & 0.21 & - & 0.20 & 38 & 34 \\
\hline Sta 3 & 83 & 540 & 120 & - & 50 & 360 & 37 & 10 & 3 & 2 & 2 & 810 & - & - & - & - & 0.08 & 0.14 & 0.19 & - & 0.32 & 25 & 237 \\
\hline Sta. 4 & 4 & 260 & 3 & 5 & 24 & 510 & 140 & 100 & 19 & - & - & 330 & - & - & - & - & 0.07 & 0.02 & 0.27 & - & 0.39 & 34 & 33 \\
\hline Sta. 5 & 2 & 250 & 4 & 3 & 29 & 85 & 88 & 78 & 1 & . & . & 120 & - & - & - & - & 0.03 & 0.02 & 0.17 & - & 0.20 & 30 & 43 \\
\hline Sta. 6 & 2 & 880 & 49 & 67 & 17 & 100 & 62 & 62 & 55 & - & - & 50 & - & - & - & - & 0.04 & 0.20 & 0.04 & - & 0.10 & 25 & 8 \\
\hline Sta.7 & - & 400 & 41 & 360 & 8.1 & 91 & 18 & 19 & 3 & . & - & 61 & $\therefore$ & - & - & - & 0.021 & 0.17 & - & - & - & 18 & 5 \\
\hline Sta. 8 & - & - & - & - & 11 & 6 & - & - & - & - & - & 14 & . & - & - & - & - & - & - & - & - & 16 & 5 \\
\hline Sta. 9 & - & - & - & - & 0.2 & 5 & - & - & - & - & - & 9 & - & 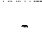 & . & - & - & . & - & - & - & 11 & 4 \\
\hline
\end{tabular}

"-" means the data was less than Detection Limit. DOC:Dissolved Organic Carbon

Table 6 Concentration of Odor Compounds in The Air of Sawerage Processes

$m m^{3} \cdot m^{-3}$

\begin{tabular}{|c|c|c|c|c|c|c|c|c|c|c|c|c|c|c|c|c|c|c|c|c|c|}
\hline 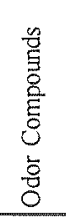 & 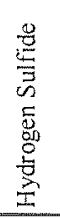 & 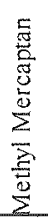 & 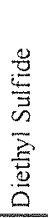 & 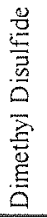 & 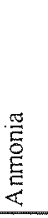 & 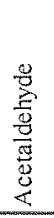 & 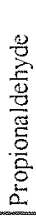 & 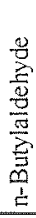 & 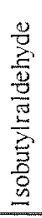 & 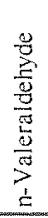 & 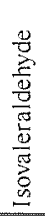 & 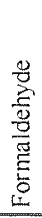 & $\begin{array}{l}\frac{D}{0} \\
\frac{1}{2} \\
0 \\
5 \\
0 \\
0 \\
0\end{array}$ & 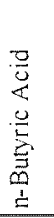 & 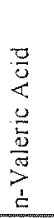 & $\begin{array}{l}\frac{D}{0} \\
\frac{8}{0} \\
\frac{0}{2} \\
\frac{0}{0} \\
0 \\
0 \\
0\end{array}$ & 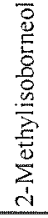 & 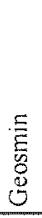 & 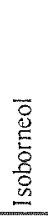 & 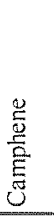 & 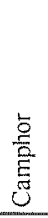 \\
\hline Sta.1 & 8200 & 600 & 59 & 76 & 10 & 54 & - & - & - & - & - & - & 0.6 & 0.7 & 0.6 & 0.2 & - & - & - & 2.3 & - \\
\hline Sta. 2 & 21000 & 1400 & 200 & 33 & 21 & 88 & - & - & - & - & - & - & 0.3 & 0.1 & - & - & - & - & - & 6.3 & - \\
\hline Sta. 3 & 1400 & 460 & 400 & 67 & 49 & 150 & - & - & - & - & - & - & 2.1 & 0.7 & 0.3 & 0.1 & - & - & - & 2.4 & - \\
\hline Sta. 4 & $4(x) 0$ & 69 & 3 & 0.4 & - & 310 & - & - & - & - & - & - & 0.1 & - & - & - & - & - & - & - & - \\
\hline Sta. 5 & 150 & 5.0 & 2 & 0.3 & 0.1 & 92 & - & - & - & - & . & - & 0.1 & - & - & - & - & - & - & - & - \\
\hline Sta. 6 & 20 & 8.9 & 14 & 1.0 & - & 120 & - & - & . & - & - & - & - & - & - & - & - & - & - & 0.9 & - \\
\hline Sta. 7 & 31 & 1.4 & 10 & 0.8 & - & 150 & - & - & - & - & - & - & - & - & - & - & - &. & - & 0.6 & - \\
\hline Sta. 8 & 2.3 & 2.2 & 3 & - & - & 90 & - & - & - & - & - & - & - & - & - &. &. & - & - & - & . \\
\hline Sta. 9 & 0.3 & - & . & - & & 99 & - & - & - & - & - & - & - & - & . & - & - & - & . & . & - \\
\hline
\end{tabular}

"-" means the data was less than detection limit

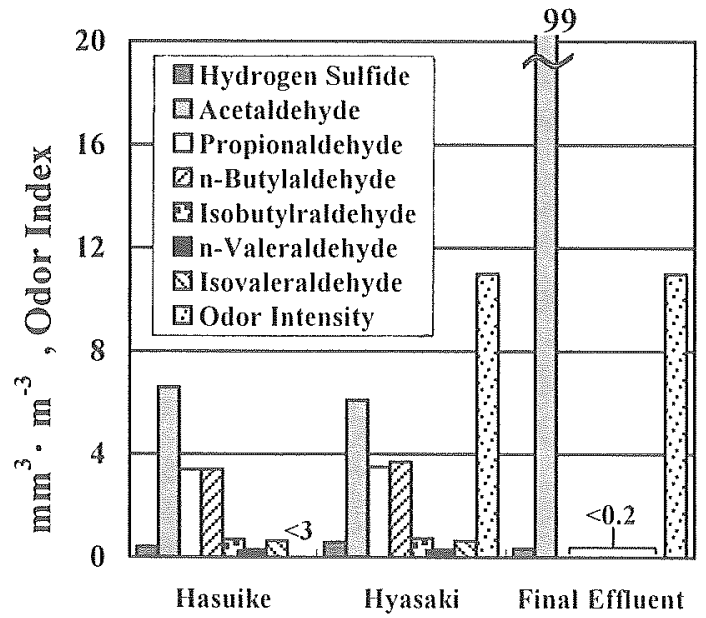

Fig. 4 Concentration of Odor Compounds in Narural Envionment
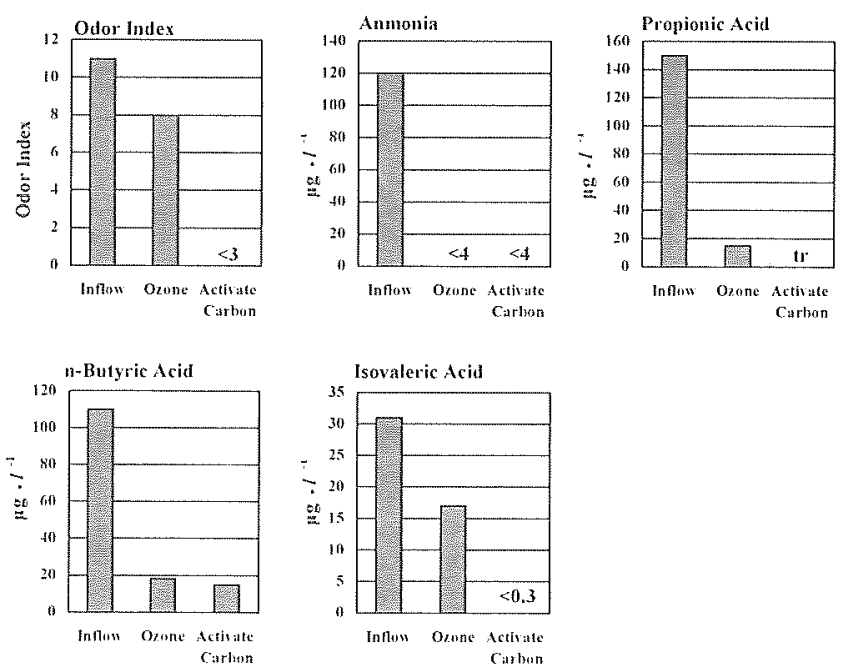

Fig. 5 Elfect of Ozone and Biochemical Activated Carbon 


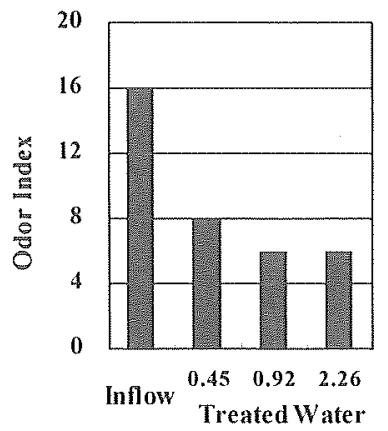

Fig. 6 Effect of Photo-catalyst and Utra-violet Treatment Odor Intex after 4 weeks proseeded. Values of treated water show UV intensity $\left(\mathrm{mW} \cdot \mathrm{cm}^{-2}\right)$.

\section{4. 考察}

3 点比較式フラスコ法で嗅覚で感知する臭気は, 試料 水中に存在していた物質がフラスコ内のヘッドスペース に出たものであり，フラスコ内の気液平衡が成り立って いることから，その分圧はへンリーの法則に従う。この ことから，文献》より得られた各物質のヘンリー定数を 用いて，各採取地点で測定された水中の臭気物質の濃度 から,フラスコ内の気相に相当するモル分圧を計算した。 これを，気体の状態方程式により気中の浱度に換算した 後, その物質の臭気闇值で除して, 閾希积倍数を計算し, 臭気指数掞よびDOC と共に Fig. 7 に示した。閾希釈倍 数とは，臭気物質の濃度を，その物質の臭気閾值で除し た值であり ${ }^{9 !}$,この值が高いほど，そのにおいの主要な 原因物質であるといえる。なお， Fig. 7ではヘンリー定 数や臭気闘值が得られなかった物質を除いた。

これによると，アンモニア，ホルムアルデヒドおよび ジェオスミンは閾希釈倍数が 1 未満であったことから，

各工程の水の系気指数には寄与していないと考えられ た。メチルメルカプタンおよび硫化メチルは好気槽出口 (Sta.7)上り上流の工程, 硫化水素は嫌気槽出口(Sta.6)上 り上流の工程で 1000 を超える閾希釈倍数であった。二 硫化メチルは，分配槽(Sta.2)，污泥処理返送水(Sta.3)㧍 よび最終沈澱池出口(Sta.8)より下流の工程では定量下限 值以下であったが，それ以外の工程では闓希釈倍数が 100 を超えていた。これらのことから，分配槽(Sta.2)と 污泥処理返送水(Sta.3)の二硫化メチルを除き，生物反応 槽を含む上流の工程(Sta.1 Sta.7)では, 含硫黄化合物 が各工程の水の臭気指数に寄与していると考えられた。

アセトアルデヒドとプロピオンアルデヒドは下流工程 ほど閾希釈倍数が低下寸る傾向が見られ，それぞれポン プ井(Sta.1)では 222 と 56 であったのが，アセトアルデ ヒドは放流水(Sta.9)で 9, プロピオンアルデヒドは好気 槽出口(Sta.7)で 15 であった。また，二れら変化はDOC 濃度の変化とも摡权連動しており, 臭気の除去と DOC の除去される工程が概初一致していると考えられた。

一般に，人が官能的に感じる「におい」が物質濃度の 刘数と比例子ることと，臭気指数がこの考えに基づき臭 気濃度の対数の10 倍の值であることから, 水中の各具 気物質濃度の対数上臭気指数の関倸を求の結果,
両側 $1 \%$ で有意な正の相関が得られたのは，アセトアル デヒド,プロピオンアルデヒドおよびホルムアルデヒド 濃度であった。これらの相関関係をFig. 8 に示した。こ のことは，本処理場ではこれらの物質の濃度が低下する に従って，水の臭気指数が低隇することを示している。

以上のこと上り，本処理場での水の臭気指数に寄与す る臭気物質が，ポンプ井(Sta.1)から好気槽出口(Sta.7)ま で存在する含硫黄化合物と，処理に伴って濃度が低下寸 るアルデヒド類によって構成されていることが考えら れ，これを模式図としてFig.9に示した。

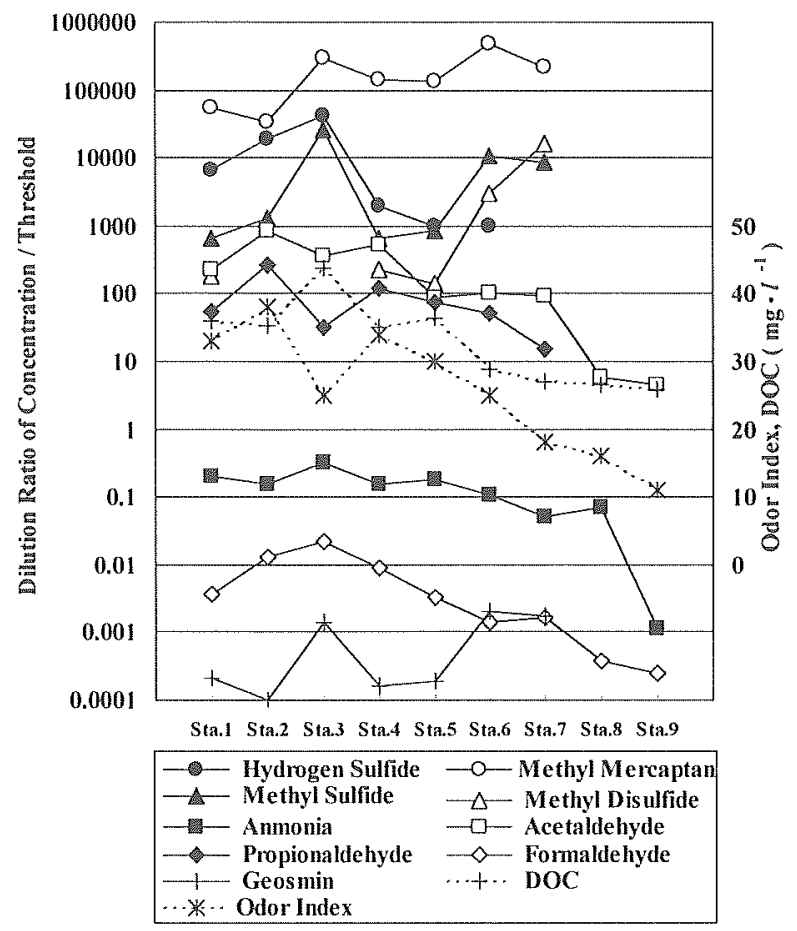

Fig. 7 Dilution Ratio of Concentration / Threshold in the head space of triangle flask method.
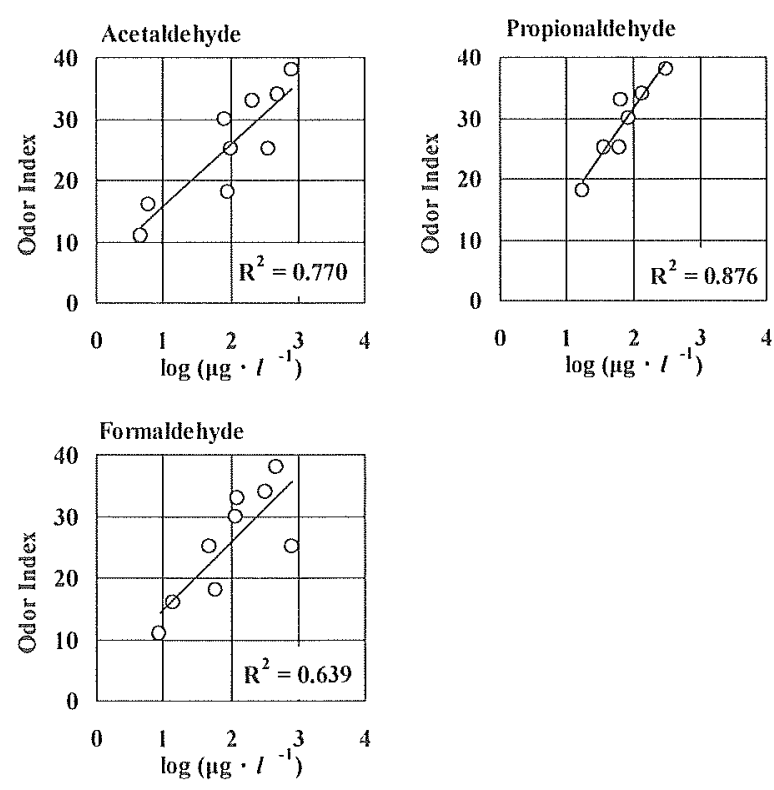

Fig. 8 Correlations of Odor Index and Odor Compound 


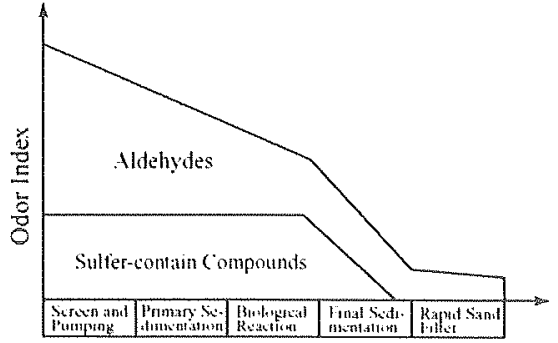

Fig. 9 The Component Compounds of Odor Index in Sewerage

各工程の大気中で検出された物質の内，硫化水素，メ チルメルカプタン，硫化メチル，硫化ジメチル，アセト アルデヒドおよびプロピオン酸が，測定地点の半数であ る5地点以上で検出された。これらの物質について，各 地点の閾希瀵倍数を求好 Fig. 10 に示した。これによ ると，ポンプ井(Sta.1)〜生物反応槽入口(Sta.5)では，二 硫化メチルを除き，含硫黄化合物の闇希釈倍数がアセ卜 アルデヒドの䦨希釈倍数と同等かそれより高くなってい るが，好気槽出口(Sta.6)以降の工程ではアセトアルデヒ ドの闎希釉倍数が高い值であった。放流水(Sta.9)では, アセトアルデヒドの闇希积倍数が 66 であったのに対し て，硫化水素の閥希粕倍数が 0.68 であり，アセトアル デヒドの閾希釈倍数が硫化水素の閾希釈倍数の約 100 倍 であった。また，放流水(Sta.9)の大気中のプロピオン酸 は闌值以下の濃度であった。これにより，下水処理の上 流工程の大気中の臭気の主要な原因物質が含硫黄化合物 であるが，下流工程，特に最終沈港池出口(Sta.8)や放流 水(Sta.9)での大気中の主要な原因物質がアセトアルデヒ ドであると考えられた。

大気中の關希釈倍数が生物反応槽(Sta.5〜 7)では低く なっており，水中の臭気物質の濃度を元に計算した気相 中の閾希棌倍数と異なる傾向であった。これは脱臭のた めの換気装置が、最初沈澱池之生物反応槽に設置されて いたためと考えられる。また, 最終沈殿池出口(Sta.8) と 放流水(Sta.9)では，施設上部が外気に開放されているこ 之が，水中の臭気物質上大気中の臭気物質の濃度が低く なる要因のひとつと考えられる。特に含硫黄化合物はへ ンリー定数が大きいので，気相に移動しやすいと考えら れる。

既存の報告によると，污泥焼却灰，アンスラサイト等 のろ過用で砂万過後の水を処理することにより，TOC および閾希橎倍数にあたる TON が $30 \sim 50 \%$ 除去され ている "”。本調查の处理場では，砂ろ過にアンスラサイ 卜と砂を併用しており，この処理工程(Sta.8〜9の間) に扔いて具気指数が 16 から11に低下して扔り，アンモ ニアとホルムアルデヒド濃度が低下していることから， アンスラサイトと砂によるろ過工程における臭気軽減が これら物質の除志によること考えられた。

自然的な水環境での調查では，放流水の大気中のア七 トアルデヒド濃度が，蓮池や早㥓内湖の約 15 倍の濃度 であったことから，本処理場で検出された大気中のアセ トアルデヒドは処理場に特有の臭気物質で女ると考えら れた。本处理場の放流水の臭気指数は法に上る規制基淮 を満たしているが，放流水が間接的に水質浄化用水とし て利用されていることから，上り上い水環境莸維持する

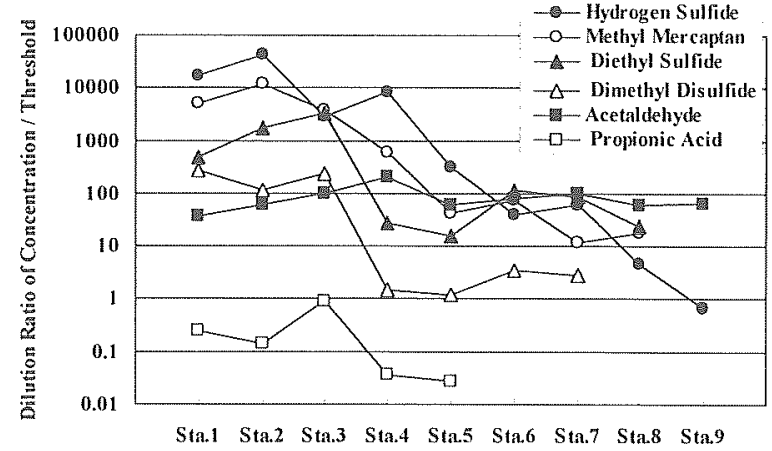

Fig. 10 Dilution Ratio of Concentration / Threshold in the air at each sewerage processes.

ためには，さらなる狊気低減刘策を実施することが望ま しいと考えられる。また，水中や気中の臭気物質濃度だ けでなく，それらから計算した闌希䣋倍数を臭気の評価 に用いるのは，臭気の原因や対策を褕討方る際に有効で ある。

オゾン処理亡生物活性炭処理による臭気低減実験で は，オゾン処理後の水の皋気指数が８であり，原水の臭 気指数 11 が大きく低隇することは無かった。これは， オゾン処理によりホルムアルデヒド や他のアルデヒ

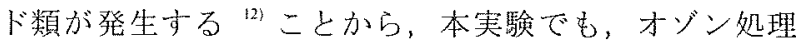
によってアルデヒド等の臭気物質が生成したためと考え られる。生物活性炭処理後で, 水の臭気指数が定量限界 以下であったのは，オゾン処理によって発生した臭気物 質が生物活性炭により除去された 媒布と紫外線による臬気低減実験では，照射する紫外線 の強度の真気低減効果八の影響は明確ではなかったこと から，本実験条件では，光触媒布表面で $0.45 \mathrm{~mW} \cdot \mathrm{cm}^{-2}$ 以 上の強度で臭気指数が低減できることが示された。

\section{5.まとめ}

水中の臭気物質濃度を測定することは, 水質管理上問 題となる物質を直接的に知ることが出来るため有用であ るが，検出された物質が官能的な臭気に対してどのよう に寄与するかは，物質濃度と臭気指数との関倸解析军 る必要がある。本研究では，悪臭防止法改正に上り，水 の臭気指数について規制基淮が追加されたことを受け，

下水処理場の各工程の大気中と水中の臭気物質の浱度を 測定するとともに，水の臭気指数との関係を解析し，次 の結果を得た。

1) 水の真気指数は, 下水処理工程が下流工程ほど低 くなる傾向が見られ，現有の下水処理でも臭気は低減さ れていることがわかった。

2) 気相の奥気物質の濃度を試料水中の物質濃度より 計算し，その物質の臭気閾値で除した「閾希釈倍数」に よると，好気槽出口(Sta.7)までの水の臭気指数に寄与寸 る主たる化合物は，含硫黄化合物であると考えられた。

3) 水の臭気指数上水中のアルデヒド類の湢度が正の 相関老持っていたことから，これら物質の濃度が低下寸 るに従って，水の自気指数が低隇していると考えられた。

4)大気中の臭気物質濃度老もとに算出した閾希釈倍 数では，上流工程では含硫黄化合物が臭気の主要な原因 
物質であり，終沈出口や放流水ではアセトアルデヒドが 臭気の主要な原因物質であることが示㖟された。

5) 本処理場の放流水直上の大気中のアセトアルデヒ ド濃度は，自然的な水環境中の約 15 倍であり，下水処 理場に特有な大気中の臭気物質であると考えられた。

6) 下水処理場の放流水の臭気対策に，オゾン処理上 生物活性炭処理による方法，および光触媒布と紫外線に よる処理が有効であることを確認した。

\section{謝辞}

本調査研究を進めるにあたり、御指導をいただいた滋 賀県琵琶湖環境部下水道計面課植松龍二課長、伊藤青史 主幹、ならびに調查を始めるにあたり資料の提供と助言 をいただいた日本下水道事業団村上孝雄博士に感謝の意 を表します。

(原稿受付 2004 年 3 月 30 日)

(原稿受理 2004 年 9 月 1 日)

\section{参慗 文 献}

1) 竹島正，西本隆之（1993）生物脱莫法の現状評価について，月 刊下水道, 16(2), 2-8.

2) 大井康裕, 丸岡礼治 (1996) 污泥処理工程の消臭用に上万臭気 対策，月判下水道，19(3)，12-17.
3) 中沢均（1999）下水道施設に扔ける莫気対策技術の概要，下水 道協会誌，36(436)，4-9.

4) 森田弘昭（2002）下水道に拉汁る硫化水素対策 下水道比扔汁 万硫化水萻の生成と噟食のメカニズム, 下水道協会誌，39(477), 10-13.

5) 月刊下水道（1999）知扎ばナットク下水道腐食対策講座 下水 中での硫化水素の生成とその速度，月刊下水道，22(12)，28-32.

6）覀臭法令研究会(2001), 四訂版ハンドブック悪臭防止法, pp.489., ぎ上うせい，東京。

7) Syracuse Research Corporation, The Physical Properties Database, http://esc-plaza.syrres.com/interkow/physdemo.htm.

8）環境庁大気保全局大気生活環境室（2000），唤覚測定法マニ二 アル，35pp，社団法人臭気詨策研究協会，東京.

9）社団法人臭気対策研究協会 (1998)，に打いの用語と解説，pp.6， 社団法人臭気対策研究協会, 東京。

10）住友恒，藤原啓助，側島義久(1991)，生物活性炭に上るホルム アルデヒドの除去，水道協会雑誌，60(9)，2-7.

11) 滝口博明, 松尾友矩, 花木啓祐, 鈴木紀之（1991）下水処理 水の再利用のための臭気物質の分析々同定, 崕生工学研究論文 集, 27, 165-173.

12) WeinbergHS, Glaze WH, Krasner SW and Sclimenti MJ (1993) Formation and Remuval of Aldehydes in Plants That Use Ozonaation, J Am Water Works Assoc, 85(5), 72-85. 